\begin{tabular}{|c|c|}
\hline & Asian Social Work Journal (ASWJ) \\
\hline $\begin{array}{c}\text { ASIAN SOCIAL WORK } \\
\text { JOURAL } \\
\text { (ASW) }\end{array}$ & Volume 4, Issue 2, March 2019 \\
& e-ISSN : 0128-1577 \\
& Journal home page: \\
& www.msocialwork.com \\
\hline
\end{tabular}

\title{
Social Marketing Approach: A Strategy to Improve the Quality of Children's Health in Communities
}

\author{
Getar Hati ${ }^{1}$ \\ 1Department of Social Welfare, Faculty of Social and Political Sciences, Universitas Indonesia \\ Corrrespondence: Getar Hati (getarhati@ui.ac.id)
}

\begin{abstract}
This article describes children health's issue as primary need to achieve their basic rights. In general, children are vulnerable to get nutrition inadequacy because they tend to consume unhealthy foods. Healthy food is a basic right that must be fulfilled to support children's growth and development. I examined two research areas identified that the problem of children in consuming unhealthy foods does not always related to the family poverty problem. This article also describes the conditions in the poor communities in North Jakarta and the intermediate community in Depok, use descriptive studies. The findings showed that children's behavior in consuming unhealthy food was due to several factors, including lack of knowledge and skills of parents or caregivers and also negative support from the social environment around children. In addition, cultural change and dynamic information technology development has greatly affected the children consumption habit. This article discusses the process description in implementing communication strategies applied for those two research areas which have different characteristics through the social marketing approach. This approach emphasizes the development of the role of all elements in the community and the intervention strategies applied in each area of the study.
\end{abstract}

Key words: social marketing, child welfare, healthy food, community health

\section{Introduction}

Health community is one of the main indicators that represent the conditions of social welfare in a society. The roles of individuals, families and local leaders are central to change their quality of life. The target of achieving the Sustainable Development Goals targeted in 2030 for health and well-being indicators to ensure a healthy life and improve the welfare of all age groups. The children-aged is a vulnerable group because most of their needs are still dependent on family/caregivers. For this reason, the achievement of welfare and child protection child welfare is always a primary target to ensure the community life quality. UNICEF (2013) states that child welfare is never separated from child protection efforts which ensure the fulfillment of children's needs to survive, grow and develop.

Mainly, children are took care in primary care by the family. Blair, et. Al. (2003) shows the results of the study that parents are the key that determines the quality of children's lives and has the duty to prepare children to become qualified future generations. The target SDGs in 2030 place health and wellbeing targets on the 3rd goal to ensure a healthy life and improve well-being for all age groups. The group of children is a vulnerable group which still largely fulfills their needs depending on parents / caregivers. Furthermore, Kirst-Ashman \& Karen (2007, p. 272) emphasize that child welfare always focuses on children and families with public services. 
The Convention on the Rights of the Child (CRC) based on the Republic of Indonesia's Presidential Decree Number 36 of 1990 concerning Ratification of the Convention on Rights of the Child affirms 4 (four) categories of ratified universal children's rights: 1) the right to survival, rights to preserve and maintain life and the right to obtain the highest standards of health and the best care; 2) protection rights, rights to get protection from discrimination, exploitation, violence and neglect; 3) developmental rights, the right to education and the right to an adequate standard of living for physical, mental, spiritual, moral and social development; 4) the right to participate (participation), the right to express an opinion in all matters affecting the child. Regarding in the context of children's rights, KPPPA (2015) also emphasizes that the fulfillment of needs and avoidance of risks relates to: (i) survival, (ii) protection, (iii) growth and development, (iv) participation, and (v) identity determine the quality of life of children as a generation of development in the future.

The efforts to achieve child welfare and protection, especially depending on fulfilling the primary needs of children, one of which is nutritious and healthy food, in order to support their growth and development. For this reason, children's food consumption behavior becomes a very urgent matter to be guaranteed. Related to food consumption behavior for children, DiNitto (2000) reflects a program implemented by the US government in the past few decades, namely Public Assistance Payment program showed that program effectiveness was only able provide adequate food for poor children at the beginning of the month or a few moments, but when in the end of the month and they have less money, food consumption behavior changed and children tend to get less nutritious food because their parents prefer to use money to pay other bills than to buy sufficient food.

The results of a study conducted by SMERU on five regions that received the Indonesian government's social assistance showed different conditions, namely that 23.6 percent of the assistance received was used to pay off debt compared to nutritious food expenditure for families (in Bappenas, 2012). This study in Indonesia then shows the condition that the availability of money in a family does not necessarily guarantee the fulfillment of good nutrition for children. This is also reinforced by the action research study (Hati, 2014 \& 2017) which showed that the habit of consuming unhealthy foods for children was not correlate directly to the condition of family poverty. Infant and toddler from poor families community in North Jakarta area tend to get unhealthy food intake because of predisposing factors which were the knowledge and attitudes that underlie parents/caregivers to carry out these habits; reinforcing factors that include the habits of husbands and large families who also have the habit of giving unhealthy food to children. In addition, there were also influences from health care workers such as Posyandu cadres who are still not optimal in reaching all citizens in educating and giving skills to mothers / caregivers. who do not provide information about child nutrition when the posyandu activity is held. Social capitals were also affects this quality of life, which related to social norms and values ultimately regulate the lifestyle of the community including the habit of providing inadequate/less nutritious food for their children (Hati, 2014). Whereas the study identified, Hati (2017) shows children in middle-income families (not poor) with different age characters, school agedchildren with ages 6-12 years, they were identified that they still depend on habitual consumption patterns by family but when they are in a wider social environment such as in communities around homes and schools, the consumption pattern also depends on peer group influence, availability of food offered, and information received by children including digital promotion through the media.

So, the problem of healthy food fulfillment is very crucial for children. This is not only become the responsibility of the family, but also the surrounding community. Social workers or community workers in health settings have a role in trying to improve this condition. Susilowati; Goddess; and Subardhini (2017) specifically describes the government's efforts in overcoming social problems of children through professional social workers involved as counselors in the Child Social Welfare Program (PKSA) called Social Workers Working Unit (herein after referred to as Sakti Peksos), where the practice referring to the National Social Workers Association (NASW) in 2013. The Sakti Peksos was less able to develop social work practice because of its dependence on the institution in which they worked and the lack of supervision from the senior social workers and the lack of capacity for development from the institution for social work practice with the children. 
Some points that can be highlighted in relation to the social work role in child welfare and protection settings in the community include the following points: Sakti Peksos as a worker social professional should continue to strive to develop knowledge and skills to be able to provide services to children, youth and their families appropriately ( $3^{\text {rd }}$ points); Advocacy: social workers should make advocacy efforts to bring about changes in the source system so that the source system can provide better services to children and their families ( $4^{\text {th }}$ point); Intervention: Social workers must remain to practice. Intervention is designed to improve the positive condition of the client and involves the child and family, other team members, school staff and appropriate service providers. Interventions should be based on sustainable assessments, objectives, evaluation methods, and outcome criteria ( ${ }^{\text {th }}$ points); and Family engagement. Social workers need to be involved in family processes, interventions and reunification efforts $\left(10^{\text {th }}\right.$ points).

Through this program, actually the government has special attention to children's social problems. However, the role of the community is also important to strive to improve the quality of life of children in their communities because the surrounding community is the closest system for children after the family system. Intervention at the community level has the opportunity to accelerate the improvement of children's quality of life in health aspects by strengthening the roles and potential that exist in the community. Ife (2013, p. 126) stated that community development in general is community-based services, which have the essence that the community must not only be responsible for delivery services but also for the identification of needs, the planning of services, and the monitoring and evaluation of program. In relation to behavioral changes related to overt and covert behavior, a model of community development is needed with a strategy of assisting groups to acquire the skills and confidence to improve the quality of life with active participation (Popple, 1995, p. 56). Twelvetrees (1991 in Popple 1995) emphasized community development models should emphasize promoting self-help by means of education. This effort becomes important to drive community awareness (conscience), namely to seek public awareness of the structure and strategies of social change which then people can participate and act effectively and also Ife (2013) emphasizes that empowerment aims to increase the power of disadvantages. As an alternative model, community-based services would focus on skill-sharing, and help community members to develop skills and use their own skills and wisdom in providing services to others. Knowledge and skills would be owned at the community level and would be shared widely among community members.

The implementation of community development model can be developed through social marketing strategies. Kotler \& Roberto (1989) define social marketing as a strategy for changing behavior, so that using socially marketed products includes ideas (practices), practices, and tangible objects that are varied according to the target group.

Two communities that have problems different condition about children's health aspects related to unhealthy food consumption behaviors have different challenges and processes. In interventions that target children under five as the main focus: the role of parents/caregivers as a primary group; and partner/extended families, local leaders, local communities as a support group. While for interventions that target school-age children, they are used as the main group and families, local leaders, schools, and local communities as a support group. Based on this background, this article discusses the process of implementing social marketing strategies carried out in two communities with different characteristics.

\section{Research Method}

This study describes the process of the program implemented in two different communities. The locus of research is in poor communities in the North Jakarta region and middle economic communities in the Depok City area. Research in these two areas involves a series of intervention efforts, the input cycle - the results of the intervention as a result of intervention studies using action research by looking at the stages of look, think, and act (Stringer, 2007). However, this article only describes the process phase of the intervention (act phase) using a descriptive approach through collecting observational data and in-depth interviewing at the community level. 


\section{Result and Discussion}

\section{Characteristic of Problem in Semper Barat, North Jakarta}

Child problems that have not fulfilled their nutritional needs, especially in children aged 6-24 months. the condition of children who are not adequately nourished is indicated by the condition of children who cannot grow and develop optimally, such as their body growth does not increase and has not been able to develop motor skills according to their age level (Hati\&Adi, 2017). Factors that bring out the existing quality of life of children, mainly due to the overt behavior (behavior and lifestyle of parents /caregivers) include: the habit of mothers providing cooked food purchased from stalls or mobile carts with a menu that does not vary; mother's habit of providing instant food; mothers providing snacks to replace the main food. Covert behavior factors which include: 1) knowledge: Mother does not know the food ingredients of food consumed by the child; mothers only assume that the most important thing is children are full, 2) perception: mothers assume that children who do not grow and develop well are born or descendants of parents; the mother considers that the child is often sick is a natural thing; mothers assume that giving snacks can replace food intake when the child is on a hunger strike; 3 ) attitude: mothers feel children do not like food cooked by the mother; mothers feel that cooking food for children is a hassle and spending more money. Reinforcing factors including the habits of spouse / extended family who participate in giving unhealthy food to children; Posyandu cadres are not optimal in providing routine information regarding child nutrition. besides, there are also social factors that affect the existing condition: the value of the community to provide food to makeshift children according to ability; value in society to prioritize husbands; and the existence of adopted norms related to "abstinence" value in providing food for children.

\section{Characteristic of Problem in Cinangka, Depok}

Hati, et.al. (2017) describes the problem of children in Cinangka Community, Depok, mostly in children aged 6-12 years (elementary school-aged) who have unhealthy food and snack consumption behaviors. Children groups in this community are the main target group in behavior change effort because they have been able to make decisions and considerations for themselves. Factors that influence children in unhealthy food and snacks consumption include overt behavior factors: 1) consuming less nutritious breakfast; 2) consuming less vegetables and fruit every day; 3 ) not able to control unhealthy snacks; and 4) not drinking enough water. Covert behavioral factors: 1) Knowledge: cannot distinguish healthy and unhealthy foods; 2) Value: judging that unhealthy food has a good taste; 3) Perception: having perceptions or depictions of foods that are processed healthy and unhealthy. Reinforcing factors: 1) parents/caregivers providing unhealthy and take no control for children accessing unhealthy snacks; and 2) no control from the environment and the school of the children behavior to consume unhealthy food outside the home.

\section{Social Marketing Approach: Promoting Healthy Food for Children}

From the results of identification mapping of child health problems, the process of attempting behavior change is organized by social marketing approach involving elements in the community: children groups: 1) infants and toddlers; 2) school-aged children; parents/caregivers (family sistem); local communities: 1) local leader; 2) local community agents: Family Welfare Program Agent; 3) youth group. Behavior changes as a result of improvements targeted on formulated from the planning based on identification of existing conditions. Social marketing as defined by Kotler \& Roberto (1989); Cheng, Kotler, \& Lee (n.d.); and Adi (2013) the design of intervention efforts was carried out in using SMART-Specific (Specific), Measured (Measurable) indicators, Achievable (Achievable), Relevant (Relevant), and Time-Bound. 


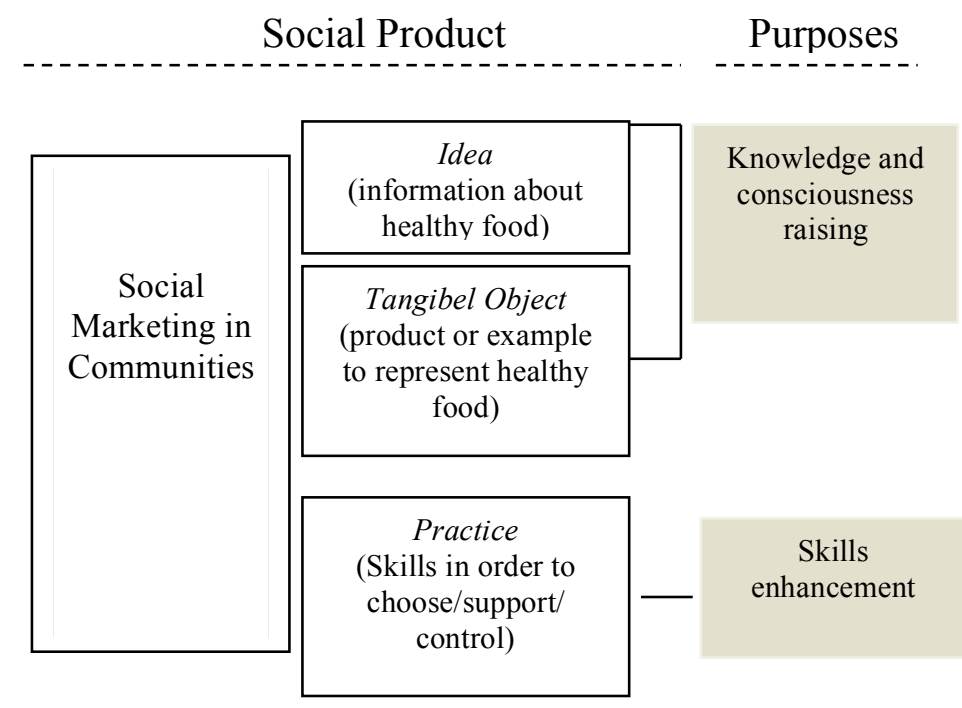

\begin{tabular}{|l|} 
Strategies \\
\hline Children Groups \\
Infants and toddlers: routine nutrition checking \\
School-aged Children: story telling, video \\
playing, role playing, poster \\
Parents/caregivers: motivation enhancement \\
Local Communities: Seminar and discussion, \\
poster
\end{tabular}

\section{Children Groups}

Infants and toddlers: -

School-aged Children: skill enhancement in healthy food choice

Parents/caregivers: communication skill enhancement; family healthy food providing skill enhancement; evaluation skill enhancement

Local Communities: communication skill enhancement (to educate, support and control)

Source: Hati, et.al. (2017)

Scheme 1. Process in Social Marketing Approach

\section{Communication Strategies for Children Group}

For infant and toddler ages children in the Semper Barat-North Jakarta community, they depend on their families so that the primary target group is parents/caregivers. Whereas for school-aged children in Cinangka-Depok community, they become the primary target group so that efforts to knowledge and consciousness raising and skill enhancement need to be targeted at this group. Through the social marketing approach, the ideas presented in order to deliver new information as base for changing their knowledge about healthy food choices and their consequences. This knowledge then targeting to enhance the awareness of children in healthy food choices. Strategies in carried out the ideas include story telling, video playing, and role playing.

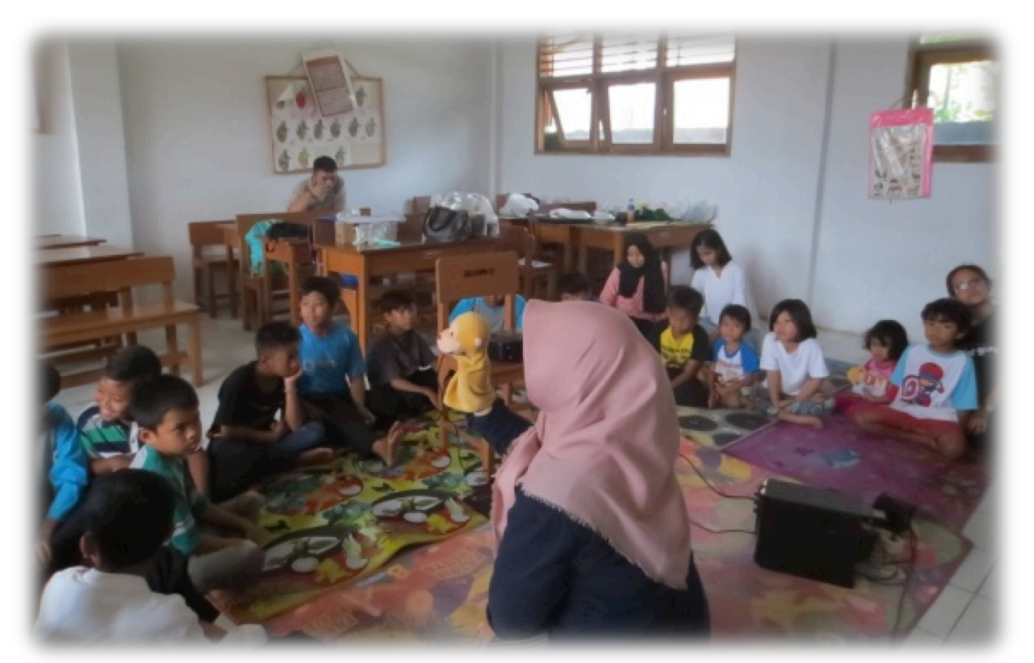

Figure 1. Story telling for children knowledge and consciousness raising Source: Hati, et.al. (2017) 
In addition, children also should maintain knowledge and awareness from information obtained in a series of activities using posters that they can see in public areas. These posters are intended to persuade them to do better behavior in choosing food.

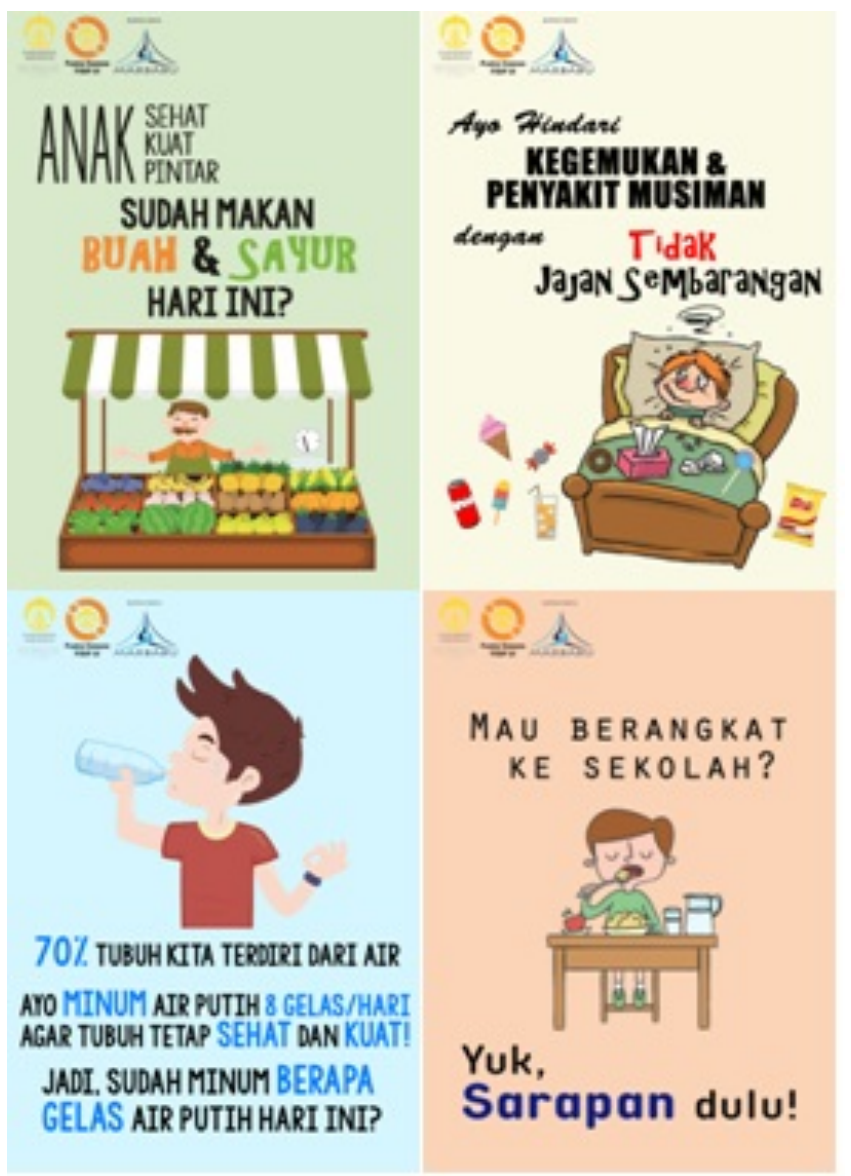

Figure 2. Poster for Children Groups

Source: Hati, et.al. (2017)

In order to skill enhancement, practice is targeted at increasing children's skills in choosing foods that are healthy and good for them. The technique is carried out through training to choose healthy and good food and training to provide healthy food independently.

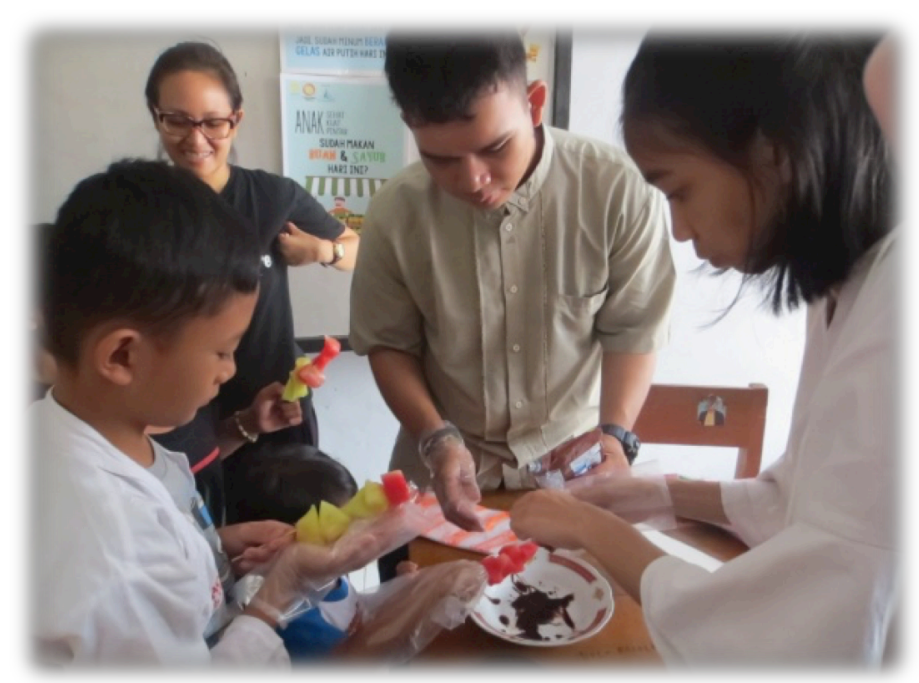

Figure 3. A child tried to make his own food Source: Hati, et.al. (2017) 


\section{Communication Strategies for Parents/Caregivers}

In Semper Barat community, North Jakarta, parents/caregivers group were the primary target group because child problems is on their fully responsibility. Related to behavioral theory as stated by Bloom (1956 in Notoatmodjo, 2007), each participant has a variety of behaviors that can be seen in cognitive, affective and psychomotor aspects. So, the social marketing approach targets changes in the three aspects of these behavior aspects.

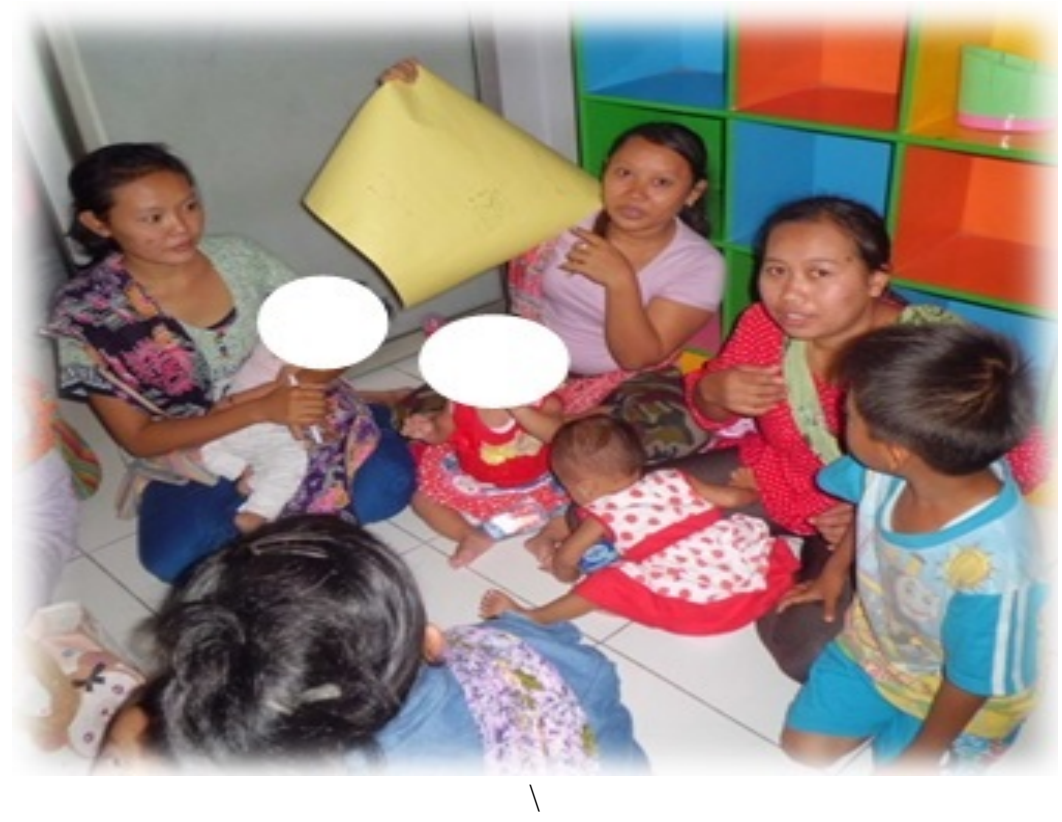

Figure 4. Knowledge and Consciousness Raising for Parents Group Source: Hati (2014)

Whereas in the Cinangka-Depok community, parents /caregivers group were categorized as supporting target groups. The intervention focused on their knowledge, awareness and skills to provide, control, and support children to eat healthy foods. The idea that conveyed was about the role of the importance of families in fulfilling children's nutritional needs as a support for children to achieve their future goals. In addition, the skills for them to communicate the best alternative ideas related to food consumption through communication and persuasion skills.

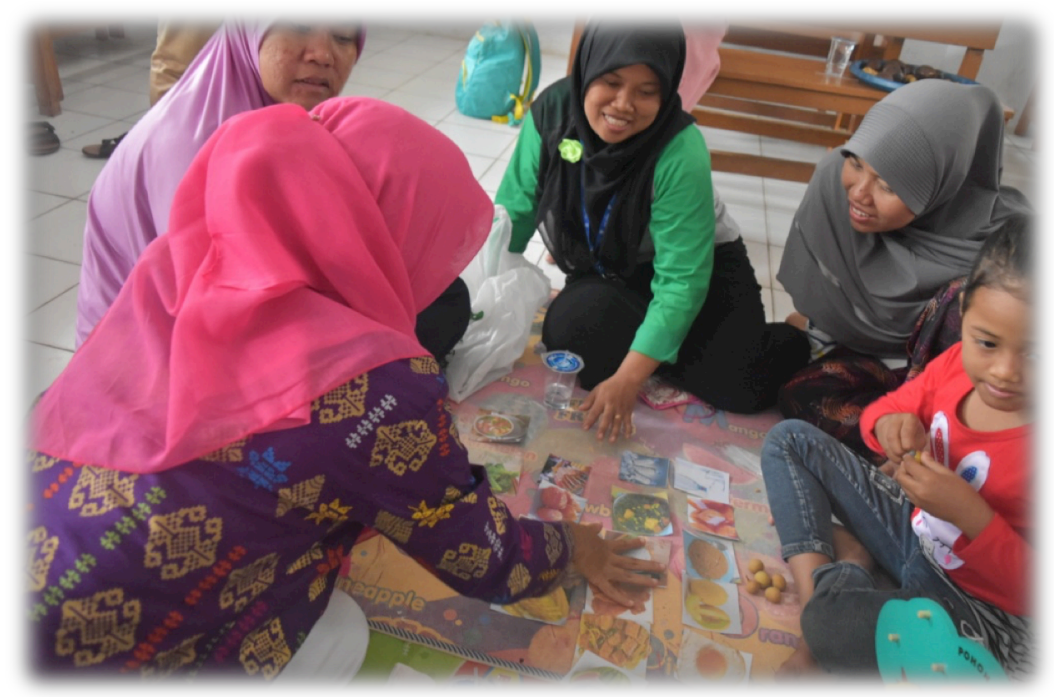

Figure 5. Knowledge and Consciousness Raising for Parents Group Source: Hati (2014) 


\section{Communication Strategies for Local Communities}

In Semper Barat-North Jakarta, we involved local leaders, children's health agents in local communities (Posyandu), and preschool teachers. They become a support group in enabling positive behavioral changes in the primary target group: parents/caregivers. For communities in Cinangka-Depok, youth groups play an active role in seeking change in their communities. Optimizing the role of youth as agents of change in their communities is carried out by strengthening their capacity to identify existing conditions, capitals, and strategies that can be implemented to achieve expected condition. Participatory mapping facilitation is needed to see the extent of children's problems related to their consumption patterns; children's access to snacks; inhibiting factors and supporting children to access healthy food; and the pattern of parenting behavior of parents, families, and communities related to the consumption of food for children (Hati, et. al, 2017).

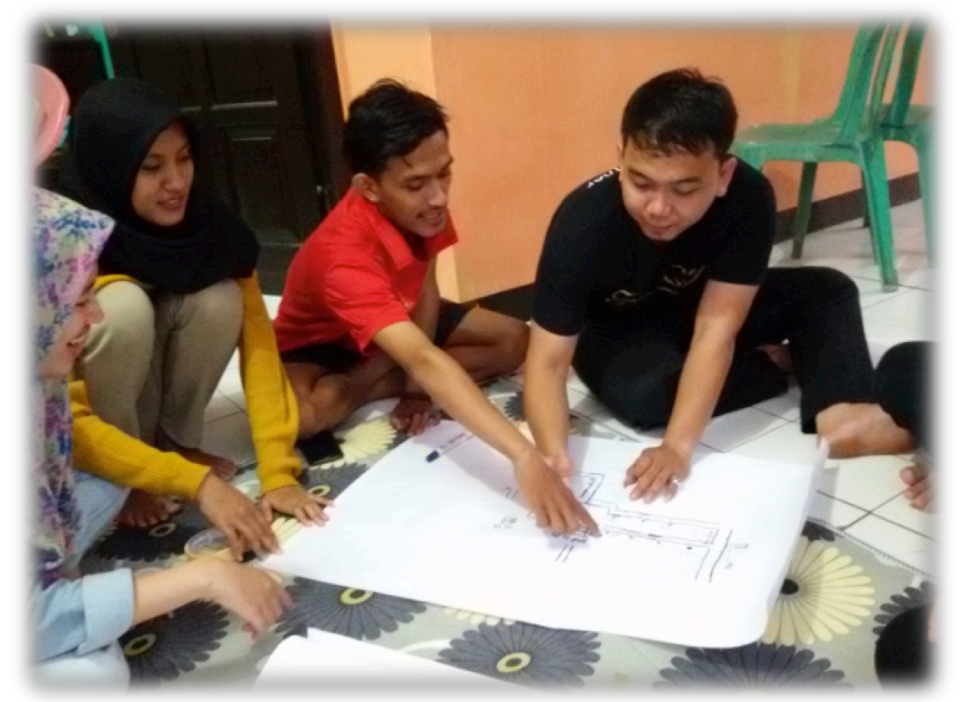

Figure 6. Youth Groups Identified their Community through Participatory Mapping Source: Hati, et.al. (2017)

Local community has responsibilities to ensure that children in their neighborhood meet their needs including nutritious food needs. In the Cinangka community, we involved local leaders and Family Welfare Program Agents (PKK cadres) to support the parents/caregivers in providing and controlling their children food consumption. To knowledge and consciousness raising, they joined in nutrition seminar and discussion. Furthermore, they developed communication skill enhancement in order to educate, support and control children and family groups in their community.

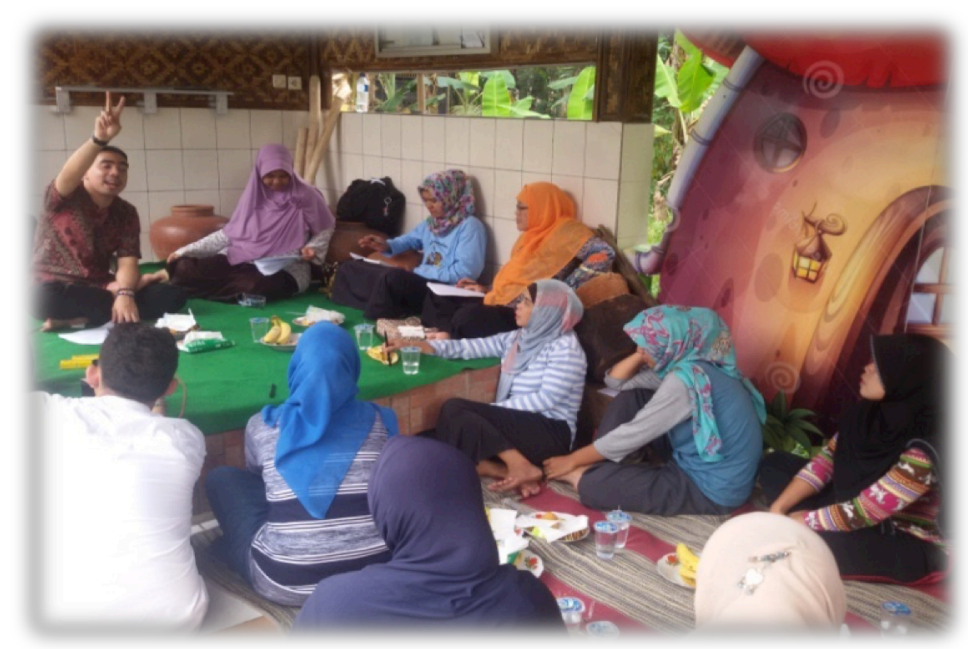

Figure 7. Nutrition Seminar for Local Leaders and Agents Source: Hati, et.al. (2017) 


\section{Conclusion}

The social marketing approach contributes to health behavior in communities through communication strategies in carrying out the ideas, tangibles objects, and practices. The process of this approach involves many strategies in order to possibly the fulfillment of child welfare and protection, especially towards health aspect. Unhealthy food consumption is not directly related to economic condition of their families, which showed on these two different communities described here. The factors behind the emergence of the problem came from the overt and covert behavior of children, parents/caregivers, extended family, and the surrounding social environment. The social marketing process targets the importance of increasing knowledge and awareness and habitual behavior through increasing skills to choose healthier and better foods, persuading healthy food consumption behaviors, supporting children and families, and controlling their behavior. This approach is an important part in achieving child welfare and protection that should be practiced holistically by social or community workers.

\section{References}

Adi, Isbandi Rukminto. (2013). Intervensi Komunitas: Pengembangan Masyarakat Sebagai Upaya Pemberdayaan Masyarakat. Edisi Revisi 2012. Jakarta: Rajawali.

Badan Perencanaan Pembangunan Nasional (2012). Laporan Pencapaian Tujuan Pembangunan Milenium di Indonesia Tahun 2011. Tanggal 17 Oktober 2013. http://www.bappenas.go.id/getfile-server/node/10299/.

Blair, Mitch, et.al. (2003). Child Public Health. New York: Oxford University Press.

Cheng, Hong., Philip Kotler., \& Nancy R. Lee. (n.d.). Social Marketing for Public Health. Jones \& Barlett Publishers, LLC. 19 Oktober 2013. http://samples.jbpub.com/.../57977_ch01_final.pdf.

DiNitto, Diana M. (2000). Social Welfare: Politics and Public Policy. USA: Allyn and Bacon.

Hati, G. (2014). Pemasaran Sosial Pemberian Makanan Sehat dan Bervariasi bagi Anak di Keluarga Miskin Perkotaan (Penelitian Tindakan pada Komunitas Ibu yang Memiliki Anak Tidak Berkecukupan Gizi Usia 6-24 Bulan di RW 04 Kelurahan Semper Barat - Jakarta Utara). Tesis: Program Pascasarjana Ilmu Kesejahteraan Sosial, FISIP UI.

Hati, G., dkk. (2017). Kampanye Sosial Makanan Sehat bagi Anak melalui Keluarga dan Komunitas. Laporan Kegiatan Pengabdian Masyarakat UI Peduli. Depok: Universitas Indonesia.

Hati, G., Adi, I.R. (2017). Proses Perencanaan, Implementasi Dan Hasil Program Perubahan Perilaku Komunitas Ibu Dalam Pemberian Makanan Sehat Dan Bervariasi Bagi Anak (Studi Penelitian Tindakan Terhadap 10 Ibu Yang Berasal Dari Keluarga Miskin Di Kelurahan Semper Barat, Jakarta Utara). Jurnal Ilmu Kesejahteraan Sosial, Jilid 17, Nomor 1, April 2016

Ife, J. (2013). Community Development in An Uncertain World: Vision, Analysis and Practice. Australia: Cambridge University Press.

Kementerian Pemberdayaan Perempuan dan Perlindungan Anak Republik Indonesia. Indeks Komposit Kesejahteraan Anak. Jakarta: 2015.

Keputusan Presiden RI Nomor 36 tahun 1990 tentang Pengesahan Convention on the Rights of the Child.

Kotler, Philip., Eduardo L. Roberto. (1989). Social Marketing: Strategies for Changing Public Behavior. New York: The Free Press.

National Association of Social Worker (2013), NASW Standards for Social Work Practice in Child Welfare. Washington DC. Socialworker.org

Notoatmodjo, Soekidjo. (2007). Promosi Kesehatan dan Ilmu Perilaku. Jakarta: Rineka Cipta.

Popple, K. (1995). Analysing Community Work: Its Theory and Practice. USA: Open University Press.

Stringer, Ernest T. (2007). Action Research. $3^{\text {rd }}$ Ed. USA: Sage Publication.

Susilowati, E., Dewi, K., Subardhini, M. The Implementation of Social Work Practice with Children in Indonesia (A Case Study of Social Work Practice with Children by Social Workers). Asian Social Work Journal, Volume 2, Issue 1, (page 28 - 38), 2017

UNICEF (2013). Ringkasan Kajian: Gizi Ibu dan Anak. Ed. Oktober. Jakarta: UNICEF. 